\title{
A Case of Bee Sting Induced Corneal Ulcer
}

\author{
Richa Dhiman*, Mandeep Tomar* and Gaurav Sharma \\ Ophthalmology Department, Dr. RPGMC Tanda, India
}

Submission: July 09, 2018; Published: September 21, 2018

*Corresponding author: Richa Dhiman. Junior resident ophthalmology Department Dr. RPGMC Tanda, H.P. India, Email: richdocs@gmail.com

Mandeep Tomar. Senior resident, Ophthalmology Department Dr. RPGMC Tanda, H.P. India, Email: sunnyigmc85@gmail.com

\begin{abstract}
Insect sting ocular damages have been reported to be associated with various insects and spiders such as bee, wasp, caterpillar, insect wings, fly larva and fire ants. Ocular bee stings are rarely reported but have the potential to cause severe sight-threatening complications. Here is a case report of an elderly female with history of multiple head, facial and ocular bee sting injuries while working in her fields. She had multiple bee sting marks over both sides of the face with some retained stingers over face. Lids were edematous with presence of 2 retained stinger on left side. A round to oval corneal ulcer of size $2.5 \times 2 \mathrm{~mm}$ was present in temporal quadrant with linear abrasions and presence of mild corneal edema and descemet's folds. On right side, a circular nebular corneal opacity was present in inferior quadrant. Management included removal of retained stinger using forceps under local anaesthesia, pad and patch of epithelial defect with antibiotic drops and ointment. Further course included frequent topical antibiotics with lubricant eye drops, following which corneal ulcer healed in a course of 3 weeks.
\end{abstract}

.Keywords: Bee sting; Cornel ulcer

\section{Introduction}

Ocular bee stings are rarely reported but have the potential to cause severe sight-threatening complications [1,2]. Some of the complications reported in the literature include: catarrhal conjunctivitis, corneal epithelial defect, corneal edema, decreased corneal endothelial cell density, corneal scarring, secondary bacterial keratitis, iris heterochromia, internal ophthalmoplegia, cataract, lens dislocation, anterior uveitis, hyphema, glaucoma, toxic optic neuropathy and chorioretinopathy [3-7]. Insect sting ocular damages have been reported to be associated with various insects and spiders such as bee, wasp, caterpillar, insect wings, fly larva and fire ants [8]. The considerable compositional differences in poison gland secretions among different bee species are thought to be a contributory factor to the wide range in the degree of response $[9,10]$. The substantial variation in clinical presentation and outcomes from case to case has made it difficult to establish a therapeutic algorithm for corneal bee stings. Among 50 articles on the topic since the earliest case report in 1955 [11].

\section{Case Report}

A 67 years old female was referred to us from otorhinolaryngology department with history of multiple head, facial and ocular bee sting injuries while working in her fields 1 day back. She had multiple bee sting marks over both sides of the face with some retained stingers over face which were removed in the emergency department. On ocular examination, visual acuity OD was $6 / 18$ improving to $6 / 9$ and $6 / 18$ os not improving with pin hole. Lids were edematous bilaterally more towards left side. Retained stinger ( 2 in number) were present on left eyelid; 1 in upper lid and 1 on lower lid. Mild conjunctival erythema and chemosis were present on left side. On left side, a round to oval corneal ulcer of size $2.5 \times 2 \mathrm{~mm}$ was present in temporal quadrant with linear abrasions surrounding it taking fluroscein uptake. there was presence of mild corneal edema along with descemet's folds. On right side, a single circular nebular corneal opacity of size $1.2 \times 1 \mathrm{~mm}$ was present in inferior quadrant. Management included removal of retained stinger using forceps under local anaesthesia, pad and patch of epithelial defect in left eye with antibiotic drops and ointment for 24 hours with daily review for slit lamp examination. Further course included frequent topical antibiotics with lubricant eye drops, following which corneal ulcer healed in a course of 3 weeks and visual acuity returned to 6/9(p) (Figure 1-5).

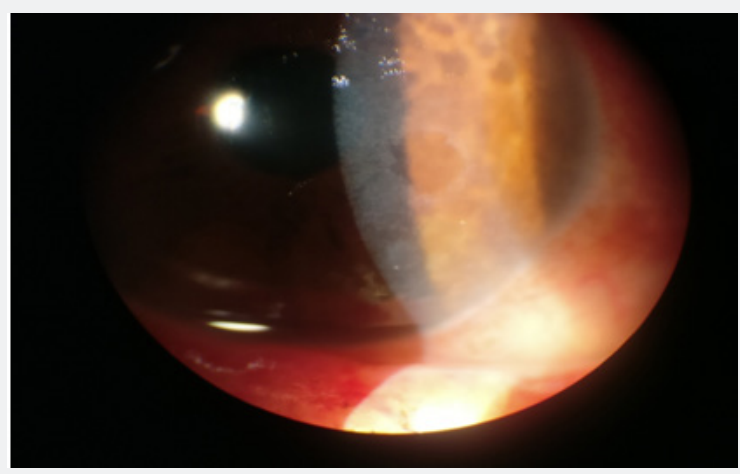

Figure 1: OS-showing corneal epithelial injury with surrounding corneal edema following bee sting 


\section{JOJ Ophthalmology}

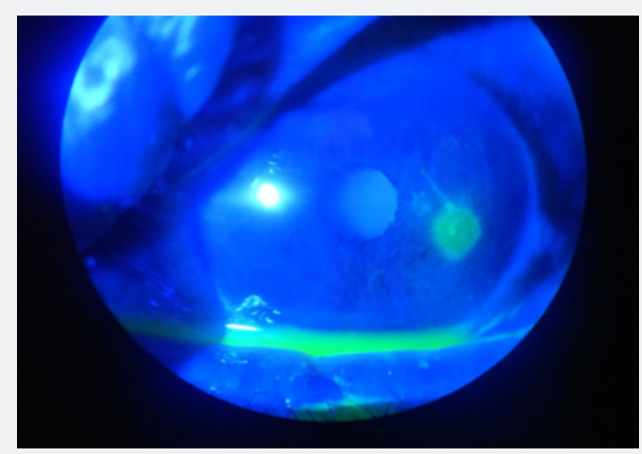

Figure 2: OS-showing corneal epithelial injury with surrounding corneal edema following bee sting
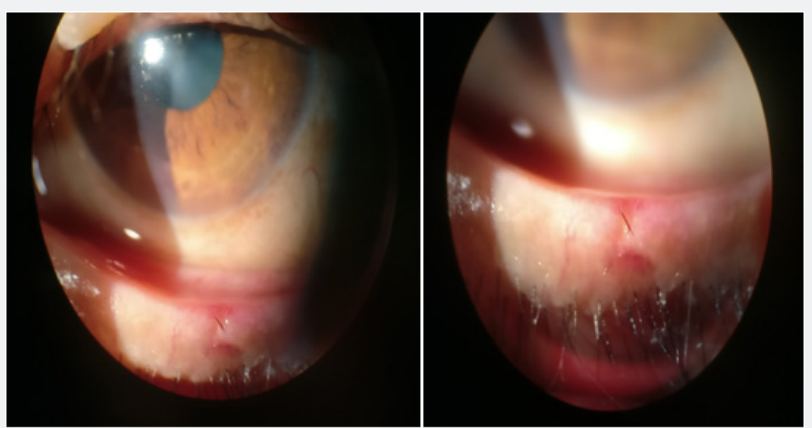

Figure 3: Embedded stinger in lower lid;removed later with forceps.

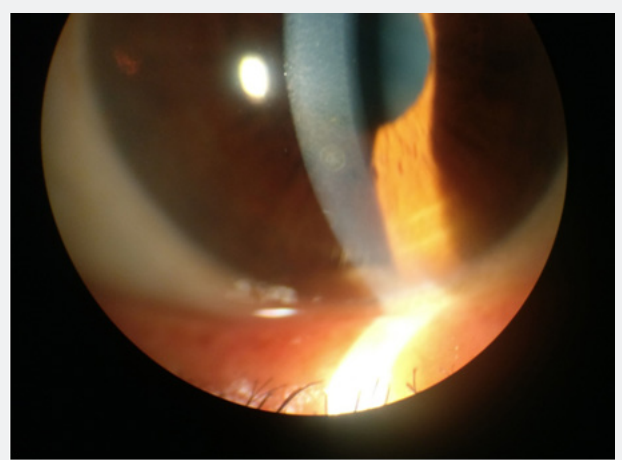

Figure 4: OS-nebular corneal opacity following bee sting.

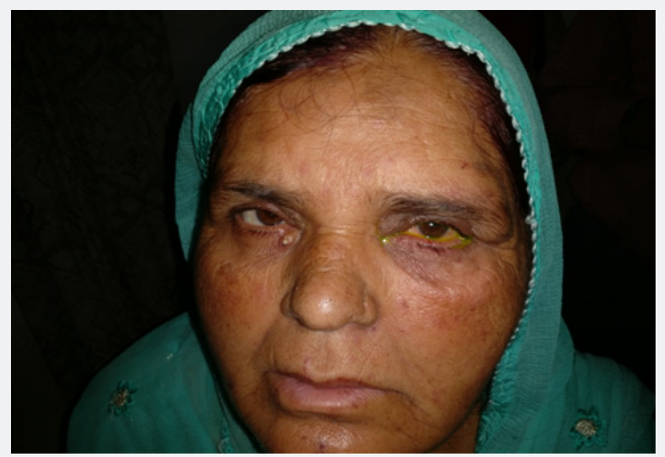

Figure 5: Picture showing remnants of multiple facial bee sting induced injuries.

\section{Discussion}

Ocular bee stings may present in a penetrating, immunologic, or toxic form or as a combination of all 3 forms. Although the response to a corneal or conjunctival bee sting is usually local, a generalized reaction such as anaphylaxis may occur in some patients who have experienced previous bee injury. Complications associated with ocular bee stings may involve the cornea, conjunctiva, anterior chamber, lens, optic nerve, or extraocular muscles $[1,2,12-14]$. It is thought that pain, hyperalgesia, and inflammation reactions associated with bee stings are most likely the result of injected bee venom, rather than the stinger itself [15]. The whole bee venom was composed of polypeptides, enzymes, amines, and so on. Major active peptidergic components of bee venom that resulted in inflammation and pain were apamin, mast cell degranulating peptide, phospholipase A2-related peptide, and melittin [16].

Chen et al. [16] presented that mast cell degranulating peptide and phospholipase A2-related peptide and melittin caused more pain-related reactions, whereas only apamin and melittin produced thermal and mechanical hypersensitivity. Apamin, which comprises about $2 \%$ of bee venom, is a neurotoxin that blocks neurotransmission via a potassium ion channel blockade $[1,12,17,18]$. In particular, melittin comprised over $50 \%$ of whole bee venom was the most potent peptide to cause inflammation and hypersensitivity [16].

Honey bee venom has a toxic effect on the corneal endothelial cells [5]. The acetylcholine in the bee venom can cause corneal edema and corneal edema after bee sting usually ends with bullous keratopathy [5].

Although there was no retained stinger at the time of presentation intracorneally, but retained stinger were present in both upper and lower lids which caused a large corneal ulcer, corneal edema and descemet's striae. It was only after removal of those stinger with forceps which lead to early healing of the corneal ulcer. Further faster recovery was aided by intensive follow up, topical antibiotics and artificial tears.

\section{Conclusion}

In conclusion, ocular surface bee stings may cause penetrating, immunologic, and toxic injuries. Though corneal bee sting injuries are rare occurrences, they are often associated with potential severe visual impairment. An immediate and prompt surgical intervention to remove the bee stinger and concurrent intensive antibiotic therapy can curtail the toxic effects of a bee sting and hence improve visual outcomes.

\section{Conflict of interest}

None.

\section{References}

1. Smolin G, Wong I (1982) Bee sting of the cornea: case report. Ann Ophthalmol 14(4): 342-343.

2. Singh G (1984) Bee sting of the cornea. Ann Ophthalmol 16: 320-322. 
3. Chinwattanakul S, Prabhasawat P, Kongsap P (2006) Corneal injury by bee sting with retained stinger. J Med Assoc Thai 89(10): 1766-1769.

4. Teoh SC, Lee JJ, Fam HB (2005) Corneal honeybee sting. Can J Ophthalmol 40(4): 469-471.

5. Grüb M, Mielke J, Schlote T (2001) [Bee sting of the cornea - a case report]. Klin Monbl Augenheilkd 218(11): 747-750.

6. Kitagava K, Hayasaka S, Setogawa T (1993) Wasp sting-induced retinal damage. Ann Ophthalmol 25(4): 157-158.

7. Gürlü VP, Erda N (2006) Corneal bee sting-induced endothelial changes. Cornea 25(8): 981-983.

8. Lin HC, Yeh WB, Chang CH, Horng JW, Yaw-Syan Fu, et al. (2006) Polymerase chain reaction identification of a hymenopteran insect in the cornea: a case report. Kaohsiung J Med Sci 22(3): 143-148.

9. Schmidt JO, Blum MS, Overal WL (1986) Comparative enzymology of venoms from stinging Hymenoptera. Toxicon 24(9): 907-921.

10. Arcieri ES, França ET, de Oliveria HB, De Abreu Ferreira L, Ferreira MA, et al. (2002) Ocular lesions arising after stings by hymenopteran insects. Cornea 21(3): 328-330.

11. Krannig HD (1955) Scleral injury caused by bee sting, with posterior cortical cataract. Klin Monbl Augenheilkd Augenarztl Fortbild 126(6) 750-753.
12. Chen CJ, Richardson CD (1986) Bee sting-induced ocular changes. Ann Ophthalmol 18(10): 285-286.

13. Yildirim N, Erol N, Basmak H (1998) Bee sting of the cornea: a case report. Cornea 17: 333-334.

14. Gilboa M, Gdal-On M, Zonis S (1977) Bee and wasp stings of the eye. Retained intralenticular wasp sting: a case report. Br J Ophthalmol 61(10): 662-664.

15. Mackler BF, Kreil G (1977) Honey bee venom melittin: correlation of nonspecific inflammatory activities with amino acid sequences. Inflammation 2(1): 55-65.

16. Chen YN, Li KC, Li Z, Shang GW, Liu DN, et al. (2006) Effects of bee venom peptidergic components on rat pain-related behaviors and inflammation. Neuroscience 138(2): 631-640.

17. Skok VI (1986) Channel-blocking mechanism ensures specific blockade of synaptic transmission. Neuroscience 17: 1-9.

18. Romey G, Hugues M, Schmid-Antomarchi H, Lazdunski M (1984) Apamin: a specific toxin to study a class of $\mathrm{Ca}+2$-dependent $\mathrm{K}+$ channels. J Physiol 79(4): 259-264.

\section{Your next submission with Juniper Publishers will reach you the below assets}

- Quality Editorial service

- Swift Peer Review

- Reprints availability

- E-prints Service

- Manuscript Podcast for convenient understanding

- Global attainment for your research

- Manuscript accessibility in different formats

( Pdf, E-pub, Full Text, Audio)

- Unceasing customer service

Track the below URL for one-step submission https://juniperpublishers.com/online-submission.php 